\title{
A ESTÉTICA DA FÉ: ECOS DE UMA DEMOCRACIA ENCURRALADA
}

\author{
THE AESTHETICS OF FAITH: ECHOES OF A CORNERED \\ DEMOCRACY
}

Lia Beatriz Teixeira Torraca'

\begin{abstract}
RESUMO: O que aproxima duas figuras políticas como Recep Tayyip Erdogan, atual Presidente da República da Turquia, e Marcelo Crivella, Prefeito do Rio de Janeiro, eleito em 2016? Buscar respostas para esta pergunta pode ajudar a compreender a atualidade política do Rio de Janeiro. Certamente năo é a religiăo que os aproximam, mas as trajetórias políticas que foram forjadas para além de uma estética religiosa. Observar a trajetória de Erdogan pode ajudar na visualizaçăo dos aspectos que identificam uma Democracia Encurralada. Através dessa observaçăo é possível verificar semelhanças que auxiliam na análise sobre as transformaçōes sofridas pela cidade do Rio de Janeiro, durante a última década, que refletem na vida política brasileira. Este artigo pretende demonstrar que a fé é capaz de transformar a percepçăo social, provocando um movimento de abertura ou fechamento do sistema social; uma estética de fé que pode ser capaz de modificar radicalmente as formas do estado e da democracia.
\end{abstract}

PALAVRAS-CHAVE: Democracia. Estética. Fé. Política.

ABSTRACT: What approximate two political figures as Recep Tayyip Erdogan, the current President of the Republic of Turkey, and Marcelo Crivella, mayor of Rio de Janeiro, elected in 2016? To search answers for this question could help to comprehend the political actuality of Rio de Janeiro. Certainly, it is not the religion that brings them closer, but the political trajectories that were forged far beyond from a religious aesthetics. To observe Erdogan's political trajectory could help us to visualize the aspects that identifies a Cornered Democracy. Through this observation, it is possible to verify similarities that support the analysis about the transformations undergone by the city of Rio de Janeiro, during the last decade, which reflect in the Brazilian political life. This paper intends to demonstrate that the faith is capable to transform the social perception, provoking an opening or closing movement of social system; an aesthetics of faith that may be able to radically change the forms of the state and democracy.

KEYWORDS: Democracy. Aesthetics. Faith. Politics.

1 Graduada em Direito pela FND - UFRJ (1992), Mestre em Direito pelo PPGD UFR (2015), Doutoranda em Direito - PPGD UFR (2015/2019). Conselheira Adjunta da Mares Editora. liatorraca@adv.oabrj.org.br 


\section{INTRODUÇÃO}

Esta proposta de análise surgiu durante a tentativa de golpe na Turquia, naquela dramática noite do dia 15 de julho de 2016, cujo desfecho se deu na madrugada do dia seguinte. Uma experiência que permitiu uma série de reflexóes, principalmente, as inevitáveis comparaçôes entre a crise turca e a brasileira, resultando em um primeiro trabalho apresentado durante o VI Seminário Fluminense de Sociologia - PPGS-UFF, em novembro de 2017, intitulado "A estética da fé: uma análise sócio-jurídica da atualidade política no Rio de Janeiro a partir do destaque de alguns aspectos da trajetória política do atual Presidente da República da Turquia".

A primeira dentre essas reflexôes foi sobre o desperdício de energia em uma disputa semântica travada no Brasil2 ${ }^{2}$, em torno da palavra golpe. Uma disputa que refletia quáo perdidos estávamos ao tentar traduzir a nossa realidade ${ }^{3}$. Enquanto preferimos esvaziar as ruas insistindo em discutir nas mídias sociais se estávamos ou năo sob a ameaça de um golpe - parlamentar, a resistência dos turcos à tentativa de um golpe militar foi imediata, comprovando-se decisiva para preservarem sua democracia contra a ofensiva dos militares, ocupando as ruas, seja para deter os golpistas, seja para festejar sua democracia É certo que a tentativa de golpe na Turquia foi muito mais fácil de ser identificada, diante da ameaça real que representou o bloqueio de pontes e estradas por militares fortemente armados, em plena sexta-feira, no horário do rush; afinal, tornar-se alvo de disparos a queima-roupa como resposta a quaisquer questionamentos ou tentativa de romper os bloqueios, náo é uma questăo que se possa permanecer discutindo por dias, meses ou anos. Nos dias que se seguiram após a tentativa do golpe militar, foi possível ouvir inúmeros relatos que vinculavam a bem sucedida resistência às conquistas democráticas, a partir de 1999, quando se desvencilharam do domínio militar; como também, à fé nos preceitos do Islá. Em praticamente todos os depoimentos, estas conquistas democráticas tinham um líder: Recep Tayyip Erdogan; um objetivo: a defesa da democracia; um alicerce: a fé.

Neste trabalho năo será abordada a imagem que a grande mídia ocidental construiu desta controvertida personalidade do cenário político da Turquia, diametralmente oposta à imagem daquele que mereceu o apoio irrestrito da populaçấo turca durante e nos meses que se seguiram à frustrada tentativa de golpe militar, tăo pouco será discutida a crise que capturou o Brasil, e que ainda é objeto de intensas disputas. O objetivo do presente artigo é buscar compreender a atualidade política no Rio de Janeiro, através de uma análise comparativa entre duas personalidades políticas que contabilizaram a fé como capital político. Um processo no qual a fé é protagonista na mudança da percepçăo social, podendo contribuir para a mobilizaçấo da sociedade ao ponto de permitir e legitimar interferências no sistema democrático, quiçá nos

2 Discussâo proposta através do trabalho intitulado "Reflexos das Manifestaçôes de Junho de 2013 no Brasil: perdidos entre disputas semânticas", em coautoria com Vinicius Azevedo, doutorando em Direito - USP, apresentado no $7^{\circ}$ Seminário Direitos, Pesquisa e Movimentos Sociais, em abril de 2018, diante da observaçăo de ambos os pesquisadores em relaçăo às disputas e divergências se estaríamos ou năo sob a ameaça de um golpe, principalmente nas mídias sociais, o que acabou provocando uma desmobilizaçăo, ou uma mobilizaçấo agendada ou concentrada em ambiente digital.

3 Há, na língua inglesa, uma expressâo utilizada quando se perde o sentido original de uma palavra ao tentar traduzi-la: lost in translation. Uma expressáo que é a traduçáo da atualidade brasileira, conforme foi exposto no trabalho apresentado no $7^{\circ}$ Seminário Direitos, Pesquisa e Movimentos Sociais (ver nota 1). 
desenhos institucionais do estado. É, portanto, sob a categoria da percepçăo que nosso trabalho recorre à estética.

A virada do milênio e o ataque terrorista de 11 de setembro de 2001 levaram Agamben, Bauman, Badiou, Rancière e outros teóricos, a discutirem sobre os desenhos do Estado, da democracia e da própria sociedade; a crise financeira de 2008 e os novos modelos de movimentos de protesto que passaram a ocupar as ruas mundo afora desde 2010, trouxeram a resistência como principal reflexăo de Harvey, Castells e tantos outros intelectuais; os dias atuais nos impóem repensar o passado, seja o processo de globalizaçâo e as reproduçôes colonialistas, como Appadurai e outros pensadores propóem, mas, principalmente, sobre as ameaças fascistas restauradas em uma atualidade que a fé preenche as lacunas das desesperanças. É uma complexa fé numa determinada linguagem política, característica da direita e extrema-direita, que associa ordem, pureza, progresso e nacionalismo. É o passado esquecido que insistimos em repetir. É esta repetiçấo que devora nossas expectativas democráticas.

Ao contrário do que possa parecer, há importantes semelhanças entre Istambul e Rio de Janeiro. É possível apontar alguns exemplos, como os processos de gentrificaçáo para modernizar as duas metrópoles e que levaram inúmeros manifestantes às ruas em junho de $2013^{4}$, guardando coincidências tanto em relaçăo à estética dos protestos quanto à reaçấo policial contra os ativistas; as duas cidades tiveram foram marcadas pela palavra golpe no ano de 2016; ambas mantém vivas as marcas do militarismo; as duas perderam o status de capital republicana, fazendo com que lutassem para manter o poder de influenciar os rumos do país, seja através do poder concedido pelo povo aos seus representantes, seja própria resistência deste povo.

Contudo, há que se observar cuidadosamente o que, a princípio, pode parecer uma diferença, como o fato do Prefeito do Rio de Janeiro, Marcelo Crivella, empreender uma espécie de fechamento e rompimento gradual com o modelo que caracteriza o Estado Democrático de Direito, ratificando a preocupaçấo dos críticos no tocante à possibilidade de influência religiosa na gestâo do município. Enquanto, Erdogan, ao contrário do que muitos supóem, acabou por inicialmente representar a abertura da República da Turquia para atender aos critérios da Uniăo Europeia e, assim, fazer parte de um modelo democrático ocidental, ainda que a adesáo social ao projeto tenha se dado através da reintroduçăo da fé no sistema político, o que acabou por encurralar a democracia turca.

4 Coincidentemente, Rio e Istambul tiveram suas rotinas convulsionadas pelos movimentos de protesto, ambos em junho de 2013. No Rio de Janeiro, a insatisfaçấo foi além dos vinte centavos de aumento à tarifa dos ônibus; em Istambul, a demoliçăo do Gezi Park fez emergir uma série de insatisfaçóes, năo só com o projeto urbanístico que se mostrou muito semelhante ao carioca, ainda que este fosse para atender aos megaeventos e lá fosse para atender ao projeto de Erdogan de integrar a Uniâo Europeia. Ambas as cidades sofreram com a reaçấo violenta do estado contra os manifestantes. Tanto nos movimentos de Istambul quanto nos do Rio de Janeiro, as mídias sociais foram os espaços de mobilizaçáo para os manifestantes, mas também foram os principais alvos de controle do estado, aproximando os dois modelos de democracia ao que Torraca chama de Democracia Encurralada*. Em 2013, durante os protestos do Gezi Park, também surgiram discussōes sobre a luta de classes das minorias étnicas e religiosas que foram expostas no documentário Chronik einer Revolte - ein Jahr Istanbul (2015), exibido no Festival do Rio 2015 (2015 Rio de Janeiro International Film Festival), e conforme o exposto pelas diretoras, Ayla Gottschilich e Biene Pilavci, durante a mesa redonda promovida pela organizaçắo do evento.

* TORRACA, Lia B. T. Democracia Encurralada: os reflexos das manifestaçóes de $\mathbf{2 0 1 3}$ no Rio de Janeiro. Rio de Janeiro: Lumen Juris Editora, 2016. 
A gestâo Erdogan pode nos ajudar a refletir sobre como a fé pode influenciar na configuraçăo política do estado, afinal, desde a vitória na guerra de independência, em 1919, e a proclamaçăo da República da Turquia, em 1923, o povo turco busca primordialmente preservar os princípios republicanos, reverenciado aquele que representa todo esses valores, Mustafa Kemal Atatürk, inclusive a laicidade. Propomos esta observaçăo que pode fazer visível como a fé, ao modificar a percepçăo social, pode permitir a reintroduçấo da religiâo ao sistema político, encurralando o próprio modelo democrático.

\section{ERDOGAN: UMA TRAJETÓRIA QUE SE CONFUNDE COM A (RE) DEMOCRATIZAÇÃO TURCA}

O primeiro degrau na trajetória política do atual Presidente da Turquia foi como Prefeito de Istambul, no período compreendido entre os anos de 1994 e 1997. Foi naquele mandato que Recep Tayyip Erdogan conseguiu costurar laços com a populaçâo de Istambul. Uma aliança que foi estratégica para a retomada de sua vida pública, após ter sido destituído do cargo, quando foi processado e julgado por ter recitado um poema durante um pronunciamento. Esta récita foi interpretada como incitaçăo a um revival do período pré-republicano, o império otomano, levando a extinçâo de seu partido (islâmico), o Welfare Party ${ }^{5}$, além da ruptura da parceria com aquele que é hoje seu arqui-inimigo, sob quem recaem as principais suspeitas de arquitetar a tentativa de golpe de 15 de julho de 2016, Fethullah Gülen. É em relaçăo a este passado ${ }^{6}$ que muitos críticos, dentro e fora da Turquia, articulam suas análises.

Em 2001, Erdogan retorna à cena política pretendendo demonstrar que havia deixado para trás a influência islâmica, recorrendo ao discurso secularista para, assim, fundar um partido conservador moderado, o AKP, o Partido da Justiça e do Desenvolvimento. Através de seu parceiro, Abdullah Gül, eleito Primeiro Ministro da Turquia, pelo entăo recém-formado AKP, Erdogan consegue anular o banimento imposto pela justiça turca, possibilitando que ele seja eleito Primeiro Ministro, em março de 2003, através do relevante apoio do eleitorado de Istambul, comprometendo-se publicamente com a democracia e a cultura democrática. Este é o ponto de partida para que Erdogan e o AKP possam empreender as reformas necessárias, em especial à constituiçăo, para romper definitivamente com o período pós-golpe militar de 1980.

A figura de Erdogan, construída durante os anos como Primeiro Ministro (14 de março de 2003 a 28 de agosto de 2014), e agora como Presidente (desde 28 de agosto

5 O Welfare Party era o maior partido do parlamento turco até ser banido pela Suprema Corte turca, sob a acusaçấo de violaçâo das obrigaçóes constitucionais, referente aos princípios seculares do Estado Democrático de Direito, "da república secular", como declarou à época o Presidente da Corte Constitucional, Ahmet Necdet Sezer, banindo também os políticos do partido. Havia a suspeita de uma oculta agenda radical do partido, conforme acusaçóes da elite secular. Disponível em: 〈https:// theguardian.com/world/1998/jan/17/turkey>. Acesso em: 19 out 2017.

60 professor Hasan Kosebalaban lembra que foi o próprio Erdogan quem declarou publicamente a incompatibilidade "entre ser muçulmano e ser secularista". Porém, o que poderia ser interpretado como uma contradiçáo do atual Presidente pode ser observada como a troca da identidade política islâmica pela visấo política liberal, prefixando como neo ou pós-islamismo, portanto nâo seria uma transformaçáo ou uma adaptaçấo da ideologia islâmica (2005). 
de 2014), foi essencial para romper o ceticismo e tentar convencer o mundo, acima de tudo, a Uniăo Europeia, que a República da Turquia rompera com um passado de ditadura militar ou com a possibilidade de um estado religioso, assumindo o compromisso de um Estado Democrático de Direito. Esta trajetória incluiu a retomada do diálogo com o PKK, Kurdistan Workers Party, acusado pelo atual governo de Ankara de ter ligaçóes com o grupo terrorista YPG; trégua esta que foi interrompida em 2015, antes de Erdogan ser mais uma vez bem sucedido nas urnas, e após as sucessivas visitas da Premier alemá, Angela Merkel, figura central nas negociaçōes entre Turquia e Uniâo Europeia.

Săo inúmeros os críticos à plataforma política de Erdogan, destacando-se particularmente o historiador Ilber Ortayli, diante da interferência e do controle no cotidiano turco em nome do estado, acentuada drasticamente após a tentativa de golpe em 2016. Sem esquecer que Erdogan era um dos principais políticos do Welfare Party, que antes de ser banido, foi acusado de promover o fundamentalismo islâmico. Porém, foi este mesmo Erdogan que transmitiu tamanha confiança ao ocidente, permitindo à Turquia ser convidada formalmente pela Comissăo Europeia, em outubro de 2004, para iniciar as negociaçóes com o intuito de integrar o seleto clube de democracias que formam a Uniăo Europeia, como salientou Steven A. Cook em seu artigo para a revista The Atlantic Magazine?.

O projeto Visăo 2023, que pretende configurar a Turquia para que possa integrar a Uniăo Europeia, foi central para o processo de (re)democratizaçăo da Turquia. Um projeto que impingiu significativas reformas nos campos político, econômico e social, para atender aos critérios formais de Copenhagen, acabando por transformar năo só a infraestrutura, mas a própria identidade da Turquia. Ao contrário do pessimismo final do século XX, a chegada do novo milênio trouxe um novo olhar dos próprios muçulmanos turcos a partir da perspectiva das parcerias que poderiam ser firmadas com as democracias europeias. Entretanto, há que se observar as tensóes internas provocadas pelo movimento de globalizaçăo, que vâo desde a discordância em relaçăo à reintroduçâo de uma agenda islâmica ao estado, até a sincronizaçăo desta mesma agenda às reformas exigidas pelo critério de pertencimento imposto pela Uniâo Europeia, o que para o Professor da Universidade Istanbul Sehir, Hasan Kosebalaban, seria o ponto crítico, responsável por impactar as percepçôes sociais.

A possibilidade de fazer parte da Uniāo Europeia significou, durante grande parte da gestăo Erdogan, uma espécie de freio aquilo que seria uma tendência ao autoritarismo ou ao islamismo radical, até perceber que as concessōes que vinha fazendo, sobretudo após a deflagraçăo da crise migratória na Europa, seja em razâo da guerra na Síria ou outros conflitos no norte da África e no oriente médio, năo surgiam o efeito desejado. Esse efeito seria a definitiva entrada da República Turca na Uniăo Europeia, o que cada vez mais, parece distante de se realizar, em especial diante do crescente nacionalismo e da ascensăo da extrema direita que vêm encurralando as democracias europeias.

7 Disponível na página: <https://www.theatlantic.com/international/archive/2016/07/how-erdoganmade-turkey-authoritarian-again/492374/>. Acesso em 21 out 2017. 
Como Erdogan conseguiu influenciar na mudança de percepçâo social durante o processo de abertura da Turquia, utilizando o conflito gerado internamente pela globalizaçāo como meio para reintroduzir a religiâo no sistema político, é uma observaçâo que pode nos ajudar a refletir sobre o poder político das igrejas pentecostais, construído a partir da mudança de percepçâo social através da fé.

\section{ERDOGAN E A MUDANÇA NA PERCEPÇÃO SOCIAL NA TURQUIA}

O primeiro aspecto que precisamos destacar é que a República da Turquia náo pode ser considerada, categoricamente, como uma ditadura ${ }^{8}$, ainda que seja possível observar retrocessos quanto às conquistas democráticas, a partir da decretaçấo do estado de emergência, após a tentativa do golpe de julho de 2016. Neste sentido, é interessante destacar a seletividade da grande mídia ocidental na repercussăo sobre as decretaçóes do estado de emergência. Vale lembrar que o estado de emergência decretado pelo governo francês, no final do ano de 2015, se mostrou muito mais próximo do conceito de estado de exceçâo permanente de Giorgio Agamben (AGAMBEN, 2004), do que o modelo excepcional adotado pelo governo turco. A insistência em diferenciá-los expóe a seletividade característica na construçâo da realidade pelas mídias ocidentais, pois o que os turcos experimentaram naquele 15 de julho de 2016, menos de 24 horas após o ataque terrorista em Nice, é tăo ou mais grave, seja em número de vítimas, seja no significado de ameaça ao estado e cidadăos, um ataque à democracia turca. Nâo podemos desprezar o aterrorizante ataque de caças ao Parlamento turco, em Ankara, sem contar os inúmeros assassinatos perpetrados pelos militares contra civis completamente desarmados. Há que se refletir sobre os sentidos seletivamente atribuídos às palavras terror e terrorismo através das construçóes políticas e midiáticas, como salienta Arjun Appadurai, em seu livro “O Medo ao Pequeno Número: ensaio sobre a geografia da raiva".

Uma República que foi atingida por três golpes militares no período Kemalista ${ }^{9}$, conforme enfatiza Jenny White (WHITE, 2013), que marcaram definitivamente a populaçăo e foram determinantes para introjetar um desejo de preservar, a qualquer custo, a democracia que ajudaram a construir, contraposta às restriçôes e à violência experimentada durante os regimes militares. Uma fé que foi - e é - determinante para a construçăo da identidade daqueles que resistiram à tentativa de golpe de $2016^{10}$.

8 A imagem de uma Turquia controlada por uma ditadura foi construída, em grande medida, pela mídia ocidental e, em minha opiniăo, nâo reflete a realidade turca.

9 Período Kemalista se refere ao período republicano, quando o Estado năo sofreu qualquer influência da religiâo islâmica, cujo grande herói foi o seu fundador, primeiro presidente, o militar Mustafa Kemal Atatürk. Ele é considerado o pai da Turquia e sua importância é ostentada em todas as paredes daquele país, seja em uma pequenina loja até as repartiçôes públicas. É tocante como os turcos preservam sua memória.

10 Ao contrário das previsóes que Erdogan decretaria estado de sítio, o Presidente turco determinou gratuidade do transporte público a partir do domingo, dia 17 de julho de 2016, durante uma semana. Naquele período Istambul se reuniu na Praça Taksim para celebrar a vitória contra os golpistas, que recebeu o nome de Festa da Democracia. Se antes a imagem de Mustafa Kemal Atatürk reinava sozinho em todas as paredes da Turquia como o pai da República turca, após a frustrada tentativa de golpe em 2016, Erdogan passou a dividir este espaço como o pai da Democracia turca. Se antes já existia uma divisăo entre kemalistas e islâmicos (White, 2002), após a vitória da democracia Erdogan contabilizou ao seu favor convergindo ambos os lados em direçấo ao seu projeto de estado. 
Uma identidade que projeta tanto o secularismo quanto a religiăo. Vale lembrar que as identidades náo se transformam com o tempo, elas sáo continuamente renovadas preenchendo a memória social, náo como algo passado, mas como acontecimento presente (LUHMANN, 2005, p. 72-73). É este modelo de democracia que reúne nacionalismo e a fé islâmica, um modelo que Erdogan soube articular e contabilizar como capital político para a manutençăo do apoio popular.

Frustrando as expectativas negativas dos kemalistas ${ }^{11}$, Erdogan representou a abertura da Turquia. Sua gestăo significou a possibilidade da participaçáo política de islâmicos na ideologia secular do estado, como pontua Jenny White (WHITE, 2013), além de ter sido muito bem recebida pelo mercado internacional, o que ajudou a formar uma percepçâo de estabilidade em torno do governo de Erdogan. Os kemalistas acabaram projetando a imagem icônica de uma "democracia autoritária" com o estilo secular ocidental, enquanto Erdogan conseguiu construir uma democracia nacionalista que coubesse alguns princípios do Islă, sem perder de vista o modelo democrático da Uniăo Europeia.

Para viabilizar a adesăo popular ao novo projeto para a Turquia, também foi necessária a alteraçâo de percepçáo do significado do que seria "oeste", o que se confunde com o próprio processo da globalizaçáo em Istambul, como observa Çaglar Keyder (KEYDER, 1999). Segundo Hasan Kosebalaban, o resultado deste "processo de interaçăo entre forças islâmicas e o mundo exterior acabou por transformar todo um conjunto de percepçóes" (KOSEBALABAN, 2005), como também foi responsável pela criaçăo de uma linguagem política turca que tornou possível o diálogo interno, e entre a Turquia e a comunidade internacional. Kosebalaban ressalta que esta construçăo só foi possível através da mobilizaçâo social acompanhada pela participaçăo institucional em níveis doméstico e global. Para o Professor, a rapidez na mobilizaçăo das forças sociais, que tradicionalmente permaneciam na periferia dos sistemas político e econômico, coincide com a liberalizaçâo desses sistemas em nível doméstico, abrindo espaço para que emergisse um islamismo turco como linguagem que tornasse possível aproveitar as oportunidades do mercado global.

Uma linguagem construída pela força da modernizaçăo e da ocidentalizaçâo que tornou Istambul uma cidade global alternativa, como definiu Tanil Bora no livro Istanbul: between the global and the local; criada através de uma narrativa política, tanto islâmica quanto nacionalista (BORA in KEYDER, 1999; p. 48). Entretanto, esta combinaçâo dos valores islâmicos e republicanos já estava incutida na sociedade (WHITE, 2013); afinal a maioria dos turcos combina em sua rotina conjuntos de crenças que podem dar a impressăo de serem incompatíveis, como "rezar e votar, aprender ciência e virtudes cívicas na escola e valores muçulmanos em casa e em suas comunidades, eles dăo esmolas e pagam taxas, eles se aconselham com Imans e levam à justiça questōes legais" (BORA in KEYDER, 1999; p. 77), ironiza Tanil Bora.

11 Segundo White, "Kemalist e Islamist săo termos autoafirmativos referentes a grupos de pessoas polarizadas reativamente em torno de certas questóes", especialmente no tocante ao modelo social e que muito se referem a percepçáo que tem uns dos outros (2002; capítulo 1 - The Political Economy of Culture). E possível dizer que os Kemalistas representam a elite turca, e os islâmicos nacionalistas representam a base de apoio do Presidente Erdogan. Um apoio que foi forjado nas camadas mais humildes da Turquia, que passaram a ter acesso à educaçấo e, portanto, à possibilidade de ascensâo social. 
Esta nova participaçăo política na Turquia emerge por intermédio da internet, responsável por trazer novos sentidos para conceitos como democracia e direitos humanos, novos olhares e novas possibilidades de produçâo da realidade. É a mobilizaçâo que Castells nomeia "movimento social em rede" (CASTELLS, 2013, p. 12), linguagem construída por uma sociedade em rede (CASTELLS, 2010). Esta nova forma de comunicaçâo só foi possível através da globalizaçâo. A abertura proporcionada pela globalizaçâo é fundamental para a sociedade turca estabelecer suas próprias confrontaçôes, como foi possível observar durante as manifestaçôes no mês de junho de 2013, em Istambul. Através dos novos canais de comunicaçâo, particularmente as mídias sociais, a populaçăo oprimida, na maioria jovem, passa a se mobilizar e confrontar o poder público, ou apoia-lo, como se verificou durante o período após a tentativa de golpe na Turquia, no dia 15 de julho de 2016.

Hasan Kosebalaban salienta que no contexto do mundo islâmico, muitas vezes marcados por sistemas repressivos de estado, o impacto da globalizaçăo é ainda maior para construir ou fortalecer a mobilizaçâo social, ainda que a maioria nâo seja acompanhada pela participaçâo de instituiçôes políticas. Sem desprezar que a globalizaçâo pode ser fonte de angústia e violência, principalmente contra as minorias, como aponta Appadurai, fazendo surgir o que ele denomina como "identidades predatórias" (APPADURAI, 2009; 46-ss), que emergem da tensăo entre identidades majoritárias e identidades nacionais, provocando verdadeiros genocídios, como forma de limpeza étnica da naçâo. Outro ponto que merece destaque é a exclusâo do mundo islâmico das decisóes que sâo concentradas nas mâos das naçôes ocidentais, ainda que afetem a todos. A sensaçăo é de que o mundo continua a ser dominado e decidido como na época do Acordo Sykes-Piccot, em conformidade com os alinhamentos das democracias ocidentais.

Umalinhamento que desenha a confusâo em torno de países que sâo majoritariamente muçulmanos, tornando mais fácil entender como a identidade islâmica acabou se transformando no vocabulário que é utilizado para expressar uma raiva contra o mundo islâmico, conforme adverte Kosebalaban (2005; p. 30). Para o autor, a globalizaçâo teria a funçâo de aliviar este sentimento, na medida em que se torna um canal de mobilizaçâo social nas instituiçôes participativas. Sem esta relaçâo, a globalizaçâo acabaria potencializando esta raiva, acredita Hasan. Todavia, a censura é uma linguagem da maioria dos regimes políticos islâmicos, responsável por provocar conflitos internos quando emerge alguma mobilizaçâo social. Mas é a própria linguagem globalizada que promoverá uma espécie de emancipaçăo social, especialmente por capacitar a interaçâo destes atores com outros, em condiçôes similares, no sistema internacional, explica Kosebalaban.

Durante este processo de globalizaçâo, a preservaçâo arquitetônica da outrora Constantinopla foi percebida como uma forma de reconquista da fé islâmica, como observa Tanil Bora (BORA in KEYDER, 1999). A autora resgata um trecho do pronunciamento de Erdogan, no qual o político aponta as mesquitas como ponto de atraçáo turística de Istambul, dando ao turista a imediata percepçấo que se "chegou a uma cidade islâmica" (KEYDER, 1999; p. 49), para explicar como Erdogan recorre à fé islâmica para imprimir uma sutil resistência à linguagem globalizada. Esta narrativa que pretende imprimir a identificaçăo religiosa ao espaço urbano é estendida à produçâo cinematográfica e 
teledramatúrgica ${ }^{12}$, multiplicando-se a projeçăo da história dos grandes momentos do Império Otomano, igualmente, como forma de empoderamento social através da reconstruçâo de uma memória permeada de vitórias e sustentada pela fé.

Uma estética que também projeta uma identidade nacionalista que năo descarta o passado, apesar dos efeitos silenciadores da gentrificaçấo, como aconteceu com os sons da cidade, que passaram a ser controlados pelo Estado e calaram a voz de inúmeros vendedores de rua para atender às novas políticas de urbanismo, como é possível constatar através do documentário "Istanbul Streets: I Hear Music", de Giulia Frati. O belíssimo trabalho de Frati retrata como o processo gentrificador em Istambul modificou radicalmente a sociedade, semelhante às transformaçóes vividas pelo Rio de Janeiro, sempre com o tradicional objetivo de atender aos projetos de modernizaçăo, seja através de Pereira Passos ou de Eduardo Paes, representantes do governo municipal do Rio de Janeiro e identificados como Prefeito do Século XX e o Prefeito do Século XXI, respectivamente.

\section{UMA NOVA PERCEPÇÃO ATRAVÉS DA FÉ}

A fé é capaz de transformar a percepçăo social provocando um movimento de abertura ou fechamento da sociedade, podendo interferir radicalmente no modelo democrático, quiçá nos desenhos do estado? Partindo do pressuposto que estética é percepçâo (ADORNO, 2004 e 2009; LUHMANN, 2005; MERLEAU-PONTY, 1999, 2015), é possível constatar năo só a alteração da percepçáo social através da fé, mas como esta é capaz de encurralar o modelo democrático, sobretudo quando é uma estética desenhada pela fé. O primeiro passo para admitirmos a possibilidade da alteraçâo da percepçăo social é que "temos muito mais percepçâo e somos muito mais influenciados pelas nossas percepçóes do que pensamos" (WATZLAWICK, 1991; p. 43). Esta influência é decisiva na determinaçâo do nosso comportamento, que acaba se refletindo no ambiente. Talvez o elemento "desigualdade social" seja essencial na dosimetria desta influência.

No caso da Turquia, ao contrário do senso comum ocidental, a modificaçâo da percepçâo aconteceu através da globalizaçáo, responsável por provocar uma mobilizaçâo social em torno da criaçáo de um modelo que acomodasse a fé aos critérios democráticos que desenham a Uniăo Europeia, flexibilizando o modelo kemalista, arraigado nos princípios republicanos, especialmente a laicidade. Neste sentido, vale registrar que a fé islâmica fazia parte da identidade turca, diversamente do Rio de janeiro, que năo carrega a identificaçăo com uma religiâo específica, pelo contrário, é a cidade de todas as religiôes, do sincretismo religioso, embora, hoje, se revele como poderoso reduto pentecostal, antes concentrado no poder da igreja católica, que se confunde com a própria colonizaçăo do Brasil. Há que se destacar a questâo da identificaçăo religiosa da cidade do Rio de Janeiro com o catolicismo, que para alguns estudiosos, é reforçada pela imagem da estátua do Cristo Redentor. Uma imagem que também acabaria identificando a sociedade carioca com o poder do cristianismo.

12 Um exemplo é o documentário "Kismet. How Turkish soap operas changed the world", da diretora Nina Maria Paschalidou. 
Ao contrário do peso que se atribui à religiăo, a alteraçăo da percepçáo social, no caso turco, deu-se em razăo da globalizaçăo, como defende Kosebalaban", "transformando percepçôes hostis em identificaçăo comum como membros de uma sociedade global" (KOSEBALABAN, 2005). Segundo o Professor, a globalizaçăo é um processo doméstico de institucionalizaçăo política que pode alterar as percepçōes, positiva ou negativamente, conforme variáveis estruturais, que incluem a possibilidade de escolha; sem esquecer o fato que a identidade determina o padrāo de julgamento, o que será essencial para uma mudança de percepçâo do indivíduo neste embate entre interno e externo provocado pela globalizaçăo.

Anthony Giddens afirma que

"a globalizaçăo năo diz respeito apenas ao que está 'lá fora', afastado e muito distante do indivíduo. É também um fenômeno que se dá 'aqui dentro', influenciando aspectos íntimos e pessoais de nossas vidas. [...] A globalizaçăo năo é portanto um processo singular, mas um conjunto complexo de processos" (GIDDENS, 2007; p.22).

O sociólogo inglês alerta para o fato que a globalizaçăo seria responsável por criar novas pressôes por autonomia local, fazendo ressurgir identidades culturais locais em várias partes do mundo, além de "brotar" nacionalismos locais como uma resposta a tendências globalizantes e ao enfraquecimento do domínio de estados nacionais mais antigos (p.23). É inegável que este processo acaba por empoderar as sociedades desprivilegiadas, provocando o efeito quem Giddens chama de colonizaçăo inversa (p.26); afinal a globalizaçăo "é apenas parcialmente uma ocidentalizaçăo" (p.26).

Esta possibilidade das sociedades náo ocidentais estimularem novas formas de percepçâo nas sociedades ocidentais, como salienta Kosebalaban, também pode provocar internamente a percepçâo da extensâo do isolamento que estas sociedades vivem, causando tensōes ou intensificando aquelas já existentes (KOSEBALABAN, 2005; p. 28), sendo justamente este conflito que Erdogan soube aproveitar para construir e consolidar seu poder político, inclusive além das fronteiras turcas.

Esta dinâmica entre insiders e outsiders, promovido pela globalizaçâo, passível de influir na mudança de percepçâo social, poderia encontrar ressonância em nosso contexto de divisăo, contribuindo para a alteraçăo da percepçăo negativa existente entre moradores do morro e moradores do asfalto, responsável por alimentar uma circularidade de violência ${ }^{14}$, que Torraca identifica como sendo característica da cidade do Rio

13 OProfessor Hasan Kosebalaban fezuma espécie deadaptaçăo do modelo de Samuel Huntington, para tentar corrigir sua insistência em ignorar o impacto transformador das instituiçóes nas percepçóes. Esta adaptaçâo ajuda também a refletir sobre concepçôes que enfatizam a identidade civilizacional islâmica como a causa do conflito, e a interrelaçấo da política doméstica com a política internacional, justamente em razăo da globalizaçâo. A chave deste modelo de instabilidade política é a modernizaçăo econômica e política, pois cria condiçóes como urbanizaçăo e incremento dos níveis de educaçâo nas naçôes em desenvolvimento e, consequentemente, a conscientizaçăo da populaçấo e seu engajamento político, conforme explica o Kosebalaban. Hasan salienta que antes da década de 90, os islâmicos turcos usaram o confronto retórico na descriçăo da posiçăo da Turquia em relaçâao ao Oeste, o que acabou se modificando nos anos seguintes a partir de um olhar mais global que acomodasse o sistema político doméstico e o estrangeiro. O atual Presidente turco foi responsável pela ascensăo do partido AKP (The Justice and Development Party) que buscou se firmar esteticamente aos democratas cristâos, alterando a percepçâo social (KOSEBALABAN, 2005).

14 Para Paul Watzlawick, a circularidade pode ser compreendida pelo "facto da maioria das interaçôes ser 
de Janeiro (TORRACA, 2016). Essas săo observaçóes que nos ajudam a pensar a divisăo no Rio de Janeiro; uma divisăo que náo é característica de Istambul. Uma divisăo que marca a estética do Rio de Janeiro, uma divisăo entre morro e asfalto, uma divisăo que é a projeçấo de uma circularidade de violência retroalimentada por profundas desigualdades. É neste ambiente de desesperança que as igrejas pentecostais têm ocupado os espaços esvaziados, seja pela ausência do estado, seja pelo crime.

Segundo Torraca, a divisâo sócio-econômica que marca a cidade do Rio de Janeiro, estabelecida entre morro e asfalto, projetaria a figura de uma Democracia Encurralada (TORRACA, 2016; p. 161-206; 2018; p. 59); um conceito que pretende explicar alguns aspectos do modelo democrático contemporâneo. Um modelo democrático que ganhou as formas de um estado de exceçăo permanente, conforme a descriçăo de Giorgio Agamben (2004), para atender à demanda construída em torno da "segurança"; uma narrativa que coloca a guerra como linguagem do cotidiano.

A Democracia Encurralada reflete uma estética herdada da ditadura militar, na qual a instituiçâo policial espelha a face militarizada do estado contemporâneo (TORRACA in ALVARES, 2018; p. 59). É o modelo que em nome da segurança cria técnicas que săo naturalmente absorvidas pela populaçăo, que dificilmente săo percebidas como instrumentalizaçōes da biopolítica. No caso do Rio de Janeiro, a Democracia Encurralada reflete uma democracia de privilégios para aqueles que vivem no asfalto, e sua completa ausência para aqueles que sofrem nas favelas (p. 59). Um modelo de democracia que na virada do milênio passou a reerguer seus muros, reconstruir suas fronteiras, cultivar suas cercas (VALLET, 2016). Uma estética que identifica a era da Antropofagia Democrática (TORRACA, 2016; p. 181-197), um fenômeno nomeado por Torraca e que está intrinsecamente relacionado à Sociedade do Espetáculo de Guy Debord (2010); uma sociedade desenhada pelo consumo e marcada pelo autoconsumo das expectativas democráticas. Uma sociedade que ao assimilar uma nova estética de comunicaçáo, concentrada na imagem e na autoimagem, na qual devora e é devorada, consome e autoconsumida. É neste processo antropofágico que a fé é potencializada como linguagem de transformaçăo, de inclusăo, de pertencimento e de empoderamento. A fé passa a compor uma sofisticada técnica política, que projeta uma promessa de libertaçấo, mas é, na verdade, apenas a transferência das rédeas da dominaçâo.

Se Erdogan contou com expressivo apoio popular para erigir um modelo que reúne a fé islâmica e o nacionalismo, entre o republicanismo e a fé; Crivella parece desejar imprimir definitivamente a fé pentecostal na rotina carioca, se colocando como representante legítimo ${ }^{15}$ da maioria para traçar rumos pouco republicanos, nada democráticos. A diferença é que no caso de Istambul, que depois se estendeu por toda República turca, havia uma fé represada pela rigidez do kemalismo para preservar os princípios

circular, com a causa a produzir efeito e o efeito transformar-se em causa fazendo feedback da causa original" (1991; p.93). Segundo o filósofo e professor de psiquiatria, "o comportamento de cada uma das partes envolvidas determina e é determinado pelo comportamento da outra" (p. 93), projetando uma dinâmica circular que leva a visóes do mundo muito diferentes; visóes alteráveis através da perspectiva.

15 Durante a intensa repercussâo contra e a favor de uma exposiçâo de arte, o prefeito Marcello Crivella, colocando-se como porta-voz do povo carioca, declarou que "o povo do Rio náo quer aquela exposiçăo de arte" (referindo-se à exposiçáo Queermuseu), notadamente, extrapolando o poder que lhe foi conferido por parte do eleitorado do Rio de Janeiro. Disponível em: <https://m.extra.globo.com/noticias/rio/ crivella-publica-video-contra-exposicao-de-arte-no-rio-21895717.html>. Acesso em: 19 out 2017. 
republicanos. Foi este o elemento-chave que permitiu Erdogan forjar uma aliança com o povo turco: a liberaçăo desta fé represada. A flexibilizaçăo do kemalismo acabou por representar a possibilidade de interferir nos desenhos do estado através de um apoio arregimentado pela fé. No caso do Rio de Janeiro, apesar da fé năo ser um elemento recente, a novidade é a utilizaçăo como capital político em uma narrativa de soluçăo para todos os problemas da cidade e da populaçấo carioca, potencializado através da alteraçăo da percepçăo social engendrada, sobretudo, nas comunidades mais pobres da cidade, o que revela um movimento inverso, fechando-se em torno da fé - da fé pentecostal.

Enquanto Erdogan foi responsável por flexibilizar a maniqueísta separaçâo entre o Islă e o Oeste, provocando a suspeiçấo da elite política e intelectual, arraigada nos princípios republicanos e que rejeitava esta nova formulaçâo impressa em um partido conservador democrata e islâmico; o Rio parece viver um processo de fechamento promovido pelas igrejas pentecostais imprimindo uma complexa conexăo entre política e religiăo.

Apesar da possibilidade do Islă ter interpretaçôes liberais e o secularismo interpretaçôes năo liberais, o discurso dominante na Turquia continua dando suporte às teorias modernistas convencionais que associam uma abertura islâmica, interpretada como "populismo", ou à corrupçăo do sistema com intençôes de manutençâo de poder. Ao contrário dos (neo)pentecostais cariocas, os muçulmanos turcos tem uma autopercepçăo solidamente construída e que identifica a sociedade turca, como também do ambiente, tanto doméstica quanto internacional, ainda que seja inegável a transformaçăo, principalmente de Istambul, para se ajustar aos moldes das democracias europeias.

Enquanto a vigilância permeia as relaçôes políticas na Turquia, por aqui a religiăo e a política ${ }^{16}$ se misturam nos moldes do barroco benjaminiano ${ }^{17}$. Constroem a imagem do político como projeçâo do divino. É a esperança do resgate, da salvaçăo através da fé. Quando Crivella promete que vai "cuidar" de seus eleitores, ele sabe exatamente o poder desta linguagem. Se estética é uma questăo de percepçăo (MERLEAU-PONTY, 2015), é também uma questăo daquilo que se constrói como realidade.

Quando observamos o discurso da "soluçâo por intermédio da política", constatamos que é a mesma estética daquele político que emerge no contexto de crise, de desilusâo, de descrença, de derrotas, como é possível verificar nos projetos de pacificaçâo: "[...] buscar a paz quando for possível alcançá-la; quando năo for possível, preparar os meios auxiliares da guerra" (HOBBES apud SATIE, 2009; p. 57). Tanto morro quanto asfalto acabam enredados numa comunicaçâo em torno da palavra guerra. É a guerra do bem contra o mal, do belo contra o feio, do puro contra o corrompido, por isso é tăo fácil que a populaçăo do asfalto nâo perceba as implicaçôes do discurso de higienizaçáo, da remoçâo branca, da gentrificaçấo. A narrativa da guerra acaba levando a populaçấo mais pobre a acreditar năo só na guerra, mas na fé como arma nas batalhas do bem

16 Zuenir Ventura expóe a influência da religiăo no cotidiano das favelas cariocas, o que também expôe uma habilidade política que cada vez mais se impóe na atualidade brasileira, como pontua Zuenir (VENTURA, 1994; p. 171,129).

17 Adorno faz referência à fábula de Baudelaire, interpretada por Walter Benjamin, sobre um indivíduo que perdeu sua auréola, numa alusăo à perda da própria aura (ADORNO, 2004; p. 153). 
contra o mal, no qual, ele - fiel, pode representar a vitória do bem, modificando sua autopercepçâo, como também, a percepçâo do ambiente. É através da fé que ele confia nos discursos religiosos, e acredita que será representado politicamente.

A conversăo religiosa é a arma nesta batalha espiritual contra o Mal, uma batalha que segundo a Professora Christina Vital da Cunha, "é um foco importante da açâo de lideranças e fieis evangélicos" (VITAL DA CUNHA, 2015; p. 253), cujo fortalecimento espiritual é a chave para a vitória. Neste sentido, a performance religiosa é essencial para construir esta identificaçâo, principalmente quando projeta a expulsâo simbólica daquilo que é percebido como maligno (p. 187; 249-250; 262; 271-272; 274). Este maligno é interpretado como o obstáculo para uma vida melhor, mais tranquila, mais segura, e seguir vivendo do lado do mal seria passível de castigo (p. 370). O problema é que esta percepçáo se coaduna com uma estética de segregaçăo que marca a cidade do Rio de Janeiro. Uma segregaçăo que nâo faz parte da sociedade de Istambul.

Na sua busca para compreender a força dos evangélicos (e de suas redes) (p. 236), Vital da Cunha descreve como opera a transformaçăo através da fé:

\begin{abstract}
"é o poder transformador de Deus e a percepçăo deles (evangélicos) em relaçăo a si próprios como mediadores deste poder na Terra. Essa autopercepçăo é legitimada por diversos atores presentes no cotidiano das favelas que váo aos evangélicos, procuram suas redes, lideranças e igrejas, na esperança de ali encontrarem proteçáo divina, aconselhamento, conforto espiritual e emocional para o enfrentamento das mais diferentes situaçôes do dia a dia" (p. 231).
\end{abstract}

Vale ressaltar que a potência pentecostal deve-se à obediência a um modelo de governo congregacional cuja principal característica administrativa, segundo a autora, seria a descentralizaçâo (p. 238-239), o que em muito explica năo só a capilaridade desta estética de fé que se projeta na formaçâo e consolidaçăo de laços afetivos e no sentido de pertencimento, além da possibilidade de uma vida beneficiada pela intervençáo divina (p.247), mediada pela autoridade pentecostal (p. 264).

Năo podemos desprezar que o poder das instituiçóes religiosas passa pelo discurso, responsável por técnicas de controle dos indivíduos. As técnicas do "fazer crer", como salienta De Certeau, "desempenham um papel mais decisivo onde se trata daquilo que ainda nâo é" (DE CERTEAU, 1998; p. 285). Estas técnicas de "fazer crer" foram absorvidas como estratégia política, principalmente na virada do século, e aprofundadas no século XXI, por partidos políticos vinculados a religióes, utilizando-se de um binômio relacionado à crença, entre a pretensâo de "falar em nome de um real" e a capacidade do discurso, autorizado por um "real" que pretende disseminar "elementos organizadores de práticas", isto é, em "artigos de fé" (p. 286).

Neste discurso está implícita uma espécie de promessa de ascensăo através da fé, um discurso de empoderamento, que muitas vezes é acusado de ser populista, talvez por assumir uma linguagem populista, ou por se revelar populista quando se constata a distância entre o discurso e a realidade. É a inclusāo social por intermédio da fé. Éa inclusâo que promove uma transformaçăo positiva na própria percepçăo da exclusăo e que recebe como retribuiçăo o apoio, o voto!

Se a religiăo é fator que caracteriza a identidade de Istambul, ainda que tenha sido possível modificá-la a partir da globalizaçăo, no caso do Rio de Janeiro a identidade 
evangélica é um elemento cada vez mais explorado nas comunidades pobres do Rio de Janeiro, "é parte da gramática das favelas e periferias do Rio de Janeiro" (VITAL DA CUNHA, 2015; p.417). Este fenômeno pode ser atribuído à projeçăo do respeito e proteçâo que porta o religioso, o que é essencial face à divisăo da cidade, afinal o asfalto representa um risco para os moradores das comunidades, e a distinçấo conferida pela imagem evangélica reduz as chances de serem "confundidos", como observa Vital da Cunha (p.106; 127).

Esta "confusâo" confirma a tese de Torraca sobre a existência de uma dinâmica circular de violência que caracteriza a violência urbana no Rio de Janeiro, cujo "comportamento de cada uma das partes envolvidas determina e é determinado pelo comportamento da outra" (WATZLAWICK, 1991; p. 93), levando essas partes a terem visóes do mundo muito diferentes. A própria divisăo da cidade reflete essas diferentes maneiras de perceber e comunicar a violência. A ordem é fixada sob uma dinâmica comunicativa de ameaça constante e recíproca, uma percepçăo disseminada pela mídia e pelo estado através do discurso do terror, e assimilada pela sociedade na forma de medo, do perigo, do risco, que passa, entâo, a exigir mais proteçăo e segurança, legitimando medidas de contençăo e controle que retroalimentam uma dinâmica circular de violência. Em nome da segurança, estabelece-se a figura de uma democracia encurralada (TORRACA, 2016).

Neste contexto, a favela é projetada como território de violência e pobreza (CORTINA, 2017), estigmas que retroalimentam a divisáo e a circularidade da violência que marca a cidade do Rio de Janeiro. Nâo por acaso a maioria da composiçăo pentecostal no mundo é formada pelos mais pobres e mais vulneráveis, econômica e socialmente, como aponta Vital da Cunha (VITAL DA CUNHA, 2015; p.185). A conversâo religiosa traz a mudança de percepçăo, tanto do ambiente quanto de si próprio, e sempre com uma conotaçăo positiva, depositando na fé, grande parte da soluçấo dos problemas cotidianos (p. 276; 343-345), além de transformarem a vergonha em orgulho (p. 209).

Vale ressaltar que o traficante é, segundo Vital da Cunha, a personificaçăo do mal, pela perspectiva pentecostal (p. 264; 273). Uma imagem que também é construída pela polícia, daí as ocupaçôes policiais nas favelas do Rio de Janeiro terem beneficiado o avanço das igrejas evangélicas, afinal o inimigo construído é o mesmo (subitem 8.2; p. 340). Outro aspecto relevante é a conversăo do traficante ser traduzida como o ápice desta guerra do bem contra o mal, o que reforça o poder dos evangélicos na comunidade (p. 366). Uma transformaçâo que identifica a paz como diferença de uma unidade de violência, chegando a alteraçôes na arquitetura das favelas, uma mudança estética através da fé. Contudo, năo é a paz uma continuaçăo da guerra por outros meios? (ARENDT, 1970; p.8).

\section{CONCLUSÃO}

Trazer uma análise da gestăo Erdogan para investigarmos a atuaçâo política de Crivella, é propor uma discussâo sobre os possíveis reflexos de uma gestăo que reintroduza a religiăo no sistema político, hoje no Rio de Janeiro, amanhá no Brasil inteiro. Se Crivella reforça a polarizaçâo social através de uma estética de fé que pretende enfrentar a violência e outros desafios impostos aos cariocas, popularizando a linguagem pentecostal como estratégia de poder político, Erdogan encontrou nos conflitos 
gerados internamente pela globalizaçăo uma chance de reintroduzir no ambiente político uma fé que estava represada na sociedade turca. Estes dois movimentos políticos projetados numa estética de fé săo capazes de interferir nos desenhos de um modelo democrático, maiormente quando contam com o apoio de grande parte da populaçáo. Um apoio que só é possível através da assimilaçăo de um discurso religioso que se conecta com a fé individual.

Se o movimento político em Istambul foi acompanhado por políticas públicas que potencializaram este apoio por terem efetivamente mudado a vida da populaçáo, no Rio de Janeiro a retórica é mais forte do que a açáo e a polêmica preenche o vazio de projetos que poderiam efetivamente enfrentar os inúmeros desafios que esta cidade apresenta.

Se antes éramos a cidade do sincretismo e da tolerância religiosa, a era Crivella pode nos fazer mergulhar em um ambiente fechado e retrógrado, cada vez mais distanciado de um modelo democrático. Pensar esses movimentos de abertura e fechamento social através de estudos comparados facilita nâo só a visualizaçâo dessas dinâmicas, mas contribui no redimensionamento do nosso olhar sobre essas transformaçôes na percepçâo social e seus reflexos, principalmente sobre uma estética de fé, que pode projetar um esquecer e repetir, referido pelo Professor Raffaele De Giorgi ao falar sobre risco:

"a sociedade esquece e repete, e através do esquecer e repetir, se expóe à evoluçăo. Isto é, se expóe à imprevisível destruiçáo das possibilidades que, com dificuldade, se abriram em direçáo ao futuro e à abertura de novas imprevisibilidades em relaçăo às quais năo se sabe o que será possível fazer." (2016; prefácio - p. 7).

Uma linguagem atualizada pelo processo de globalizaçáo, pelo medo, ou por uma violência comunicada, seja derrubando ou erigindo muros em nome da fé, encurralando a própria democracia. 


\section{REFERÊNCIAS}

ADORNO, Theodor W. Teoria Estética. Madri: Ediciones Akal, Madrid, 2004.

ADORNO, Theodor W. Dialética Negativa. Rio de Janeiro: Zahar Editora, 2009.

AGAMBEN, Giorgio. Estado de Exceçāo. Homo Sacer, II. Săo Paulo: Boitempo, $2^{a}$ ediçăo, 2004.

ARENDT, Hannah. Da Violência. Download da obra, disponível na página: <http://www. libertarianismo.org/livros/harendtdv.pdf>. Acesso em: 13 set 2014.

APPADURAI, Arjun. O Medo ao Pequeno Número: ensaio sobre a geografia da raiva. Sáo Paulo: Iluminuras: Itaú Cultural, 2009.

CASTELLS, Manuel. Redes de Indignaçāo e Esperança: movimentos sociais na era da internet. Rio de Janeiro, RJ: Editora Zahar, 2013.

CASTELLS, Manuel. A Sociedade em Rede. Volume I. Sâo Paulo, SP: Editora Paz e Terra Ltda., 2010.

CORTINA, Adela. Aporofobia, el rechazo al pobre. Barcelona: Espasa Libros, 2017.

DEBORD, Guy. La Société du Spectacle. Download do arquivo <http://www.fichier-pdf. fr/2012/10/20/societe-spectacle2/societe-spectacle2.pdf>. Acesso em: 25 ago 2013.

DE CERTEAU, Michel. A Invençâo do Cotidiano. Artes de Fazer. Petrópolis: Editora Vozes, 1998.

GIDDENS, Anthony. Mundo em descontrole. Rio de Janeiro: Editora Record ltda., $6^{\mathrm{a}}$ ediçăo, 2007.

KEYDER, Çaglar. Istanbul: between the global and the local. Maryland: Rowman \& Littlefield Publishers, Inc., 1999.

KOSEBALABA, Hasan. The Impact of Globalization on Islamic Political Identity. The Case of Turkey. Sage Publications, vol. 168 - no.1 - summer 2005; pp. 27-37.

LUHMANN, Niklas. A Realidade dos Meios de Comunicaçāo. Săo Paulo: Paulus, 2005.

LUHMANN, Niklas. El arte de la sociedad. México: Editorial Herder, 2005.

MERLEAU-PONTY, Maurice. O primado da percepçāo e suas consequências filosóficas. Belo Horizonte: Autêntica Editora, 2015. 
MERLEAU-PONTY, Maurice. Fenomenologia da Percepçāo. Săo Paulo: Martins Fontes, 1999.

SATIE, Luis. Teoria Estética do Direito: um estudo da forma em Kant, Hegel e Adorno. Săo Paulo: Clube de autores, 2009.

TORRACA, Lia B. T. Democracia Encurralada: os reflexos das manifestaçōes de 2013 no Rio de Janeiro. Rio de Janeiro: Lumen Juris Editora, 2016.

TORRACA, Lia B. T. A Cornered Democracy: The Echoes of the 2013 Demonstrations in Rio de Janeiro and the Architecture of a Crisis. In: ALVARES, Lucia Capanema e Barbosa, Jorge (eds). Urban Public Spaces: From Planned Policies to Everyday Politics. Cham, Suíça: Springer Nature, 2018.

VALLET, Elisabeth A. Borders, Fences and Walls: State of Insecurity? London: Routledge, 2016.

VENTURA, Zuenir. Cidade Partida. Sáo Paulo: Companhia das Letras, 1994.

VITAL DA CUNHA, Christina. Oraçâo de Traficante: uma etnografia. Rio de Janeiro: Garamond, $1^{\text {a }}$ ediçăo, 2015.

WHITE, Jenny B. Muslim nationalism and the new Turks. New Jersey: Princeton University Press, 2013.

WHITE, Jenny B. Islamist mobilization in Turkey: a study in vernacular politics. Seattle: University of Washington Press, 2002.

WATZLAWICK, Paul. A Realidade é Real? Lisboa: Relógio d 'Água Editores Lda., 1991.

RECEBIDO EM: 30/05/2018

APROVADO EM: 24/09/2018 